\title{
Danske jordskaelv - 200 registrerede jordskaelv på 75 år
}

Af Martin Glendrup, Søren Gregersen og Peter Voss, GEUS

I Danmark registreres hvert år 5 til 10 jordskælv. Mulighederne for at opdage jordskælv i det danske område er i de senere år blevet betydeligt forbedret.

Den klassiske artikel om de danske jordskælv blev skrevet af Inge Lehmann i 1956, der på dette tidspunkt evaluerede alle historiske seismiske hændelser, der var kendt på den tid. Udvælgelsen resulterede i en liste på 50 jordskælv, der var følt i Danmark mellem 1073 og 1954. 13 af disse blev frasorterede, da man mente, at det, der var blevet følt, var andet end et jordskælv. Allerede i denne tidlige undersøgelse kunne det vises, at de mest aktive zoner i det danske område ligger i Skagerrak/nordvest Jylland og i Kattegat/ Øresund/nordøst Sjælland

200 jordskælv i Danmark siden 1929 Fra 1929 til 2004 er der blevet lokaliseret 200 jordskælv i Danmark ved brug af computere. Datamængden fra størstedelen af jordskælvene har været så stor, at det har været muligt at placere jordskælvene geografisk med en usikkerhed på 5 til $10 \mathrm{~km}$. I første halvdel af perioden fra 1929 til 1967 er der registeret 7 jordskælv, mens der fra 1968 til 2004 er registreret 193 jordskælv. Stationsnettet er stærkt forbedret de sidste 30 år.

Danmark har i øjeblikket 12 stationer på Grønland og 5 seismografer i det danske område. Figuren ovenfor viser stationernes placering i Mønsted, København, Gilleleje, Stevns og på Bornholm samt de knap 200 danske jordskælv, der er blevet lokaliseret hos GEUS sammen med de jordskælv, der er registreret i Norge.

Aktiviteten er tydeligvis størst i Kattegat og Skagerrak/Nordvestjylland, mens der ingen eller ringe aktivitet er i den sydlige del af Jylland, på Fyn og syd Sjælland. Generelt er der ikke megen aktivitet syd fra en linje, der går ved den store koncentration i Nordsøen og videre øst på mod Rügen. Dette kunne måske have forbindelse med den sydlige afgrænsning af det Baltiske skjold.

\section{Følte jordskælv i Danmark i år} I 2004 har der været to jordskælv, der er blevet følt i Danmark. Den 23/2 2004 blev

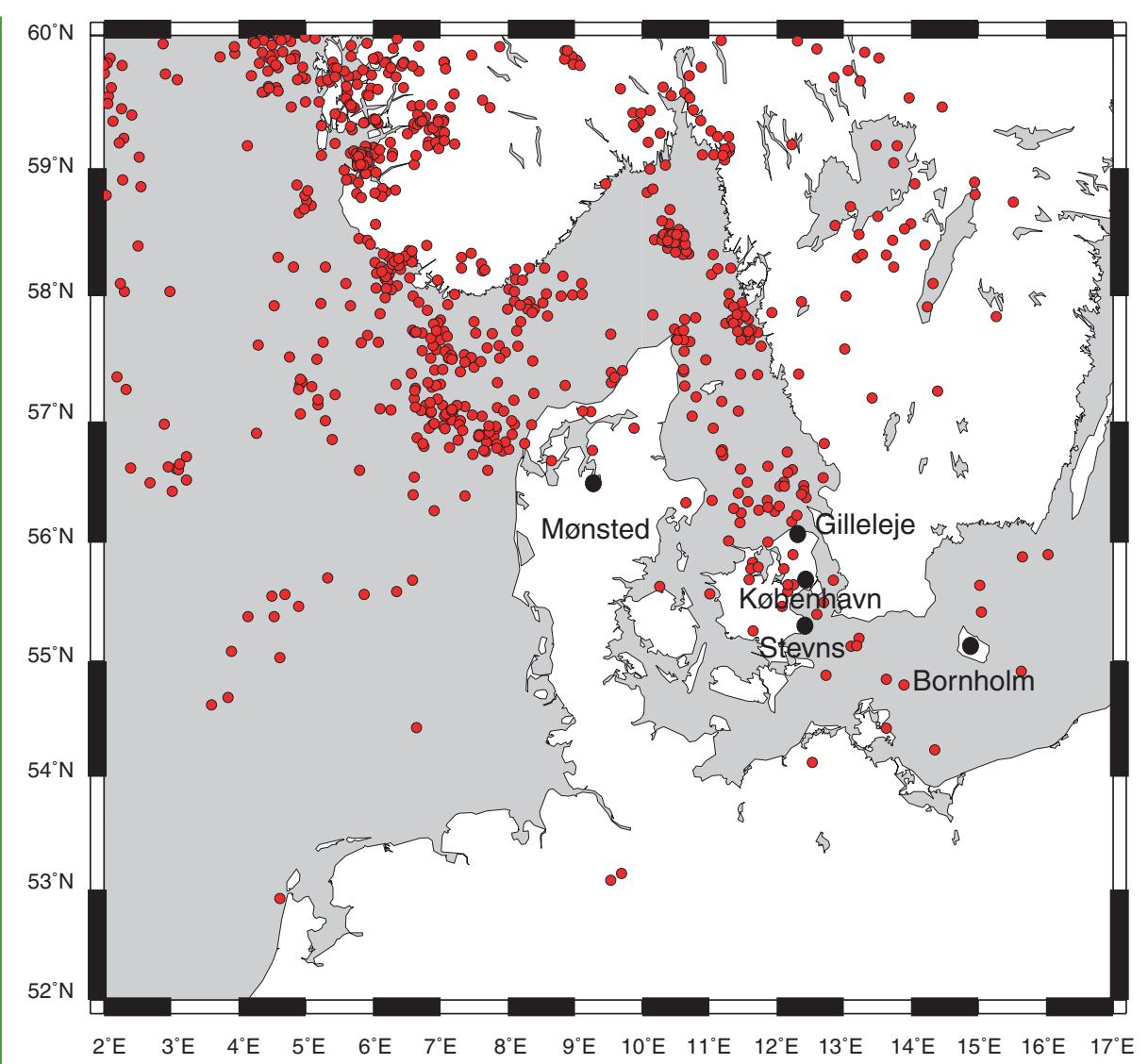

Jordskalv registreret af GEUS og Bergen Universitet gennem de sidste 75 år. Jordskalvene målt af Bergen Universitet er over 2 på Richterskalaen og lokaliseret ved hjcelp af over 5 seismiske stationer. (Grafik: Martin Glendrup og Peter Voss)

området omkring Køge rystet af et jordskælv, der målte 3 på Richterskalaen og et meget kraftigt jordskælvi Kaliningrad den 21. september, der målte 5,5 på Richterskalaen. Jordskælvet i Kaliningrad var så kraftigt, at det blandt andet medførte, at rådhuset $i$ Landskrona blev evakueret. Tilsammen er de blevet rapporteret til GEUS af over 300 mennesker.

Figuren på næste side viser udslaget på den vertikale kanal på seismograferne på København, Gilleleje, Bornholmog Mønsted på tidspunktet for jordskælvet få km vest for Køge den 23. februar $2004 \mathrm{kl} 8.38$ UTC dvs. 9.38 dansk tid. Signalet er meget tydeligt, man kan se, hvordan den primære seismiske bølge ankommer først på stationerne på Sjælland og derefter er registreret på stationerne på Bornholm og i Mønsted med 5 sekunders mellemrum. Jordskælvet blev følt af over 100 personer på Sjælland, der rapporterede til GEUS ofte med den forkla- ring, at rystelserne havde fået dem til at tro, at der var en stor lastvogn, der parkerede i deres baghave.

\section{Fokal-mekanismer}

Selvom de danske jordskælv er små, giver de informationer om det stress, der er udløst, det vil sige om, hvordan bevægelsen i forkastningen har været, og i hvilken retning forkastningen går, den såkaldte fokal-mekanisme.

Mekanismen kan for de største hændelser beregnes til at vise kompression i en nordvest sydøstlig retning, hvilket også ses i resten af Skandinavien. Dette stressfelt er en del af det mønster af kompression, der findes langs lithosfære-pladebevægelserne på begge sider af det Nord-Atlantiske Ocean. Dette dominerende stressfelt kan ændres ved småskala-inhomogeniteter, som giver anledning til jordskælv, der ikke passer ind $\mathrm{i}$ dette mønster. Et sådant område er i Katte- 
gat mellem Sverige og Danmark. Mange slags fokal-mekanismer er blevet observeret der. Idet stressfeltet i Skandinavien var signifikant anderledes for 9.000 år siden lige efter istiden, hvor iskappen havde den afgørende indflydelse, har det været påpeget, at stressfeltet har ændret sig drastisk siden.

Jordskælv sker i forbindelse med forkastningszoner, og man kunne derfor tro, at det var muligt at forbinde jordskælvene med allerede kendte forkastningszoner, der kunne være anledning til jordskælvene. Dette har været testet med succes for dele af det danske område, men var ikke gældende for andre dele. Den vigtigste forkastningszone nær Danmark, Sorgenfrei-Tornquist-zonen deformeres kun delvist. Dette er for nylig blevet undersøgt geodætisk og seismologisk.

Sammenligning af 2 årtiers jordskælv Den mest aktive zone i Skagerrak har tidligere været genstand for en speciel undersøgelse. Denne zone er igen nævnt i forbindelse med de kendte jordskælv i Nordsøen og der var her ikke nævnt noget om jordskælv i Central Graven. I en senere artikel er de samme zoner i Skagerrak og i Kattegat udpeget, men her er også nævnt en lineation af aktivitet i Central Graven. Dette kunne give en indikation på, at jordskælvsaktiviteten ændrer sig, hvis man ser detaljeret på den.

Figuren på næste side viser lokaliseringen af jordskælv fra to forskellige tiår. Fra 1983 til 1992 er der 55 velbestemte jordskælv, mens der er 79 velbestemte jordskælv i perioden 1993 til 2002. Selv om det overordnede billede er det samme, kan man alligevel se små variationer, hvilket stemmer overens med, hvad man ser $\mathrm{i}$ andre dele af verden, hvor man ligeledes kan se små ændringer med tiden. På figuren næste side ses en forskel i den nordlige del at Skagerrak og omkring Sorgenfrei-TornquistZonen.

Jordskælvsaktiviteten må overvåges over en lang periode, så man får et dækkende billede. Store historiske jordskælv er forekommet i de zoner, der er vist på figuren næste side. Men ligesom de sidste 10 år gav

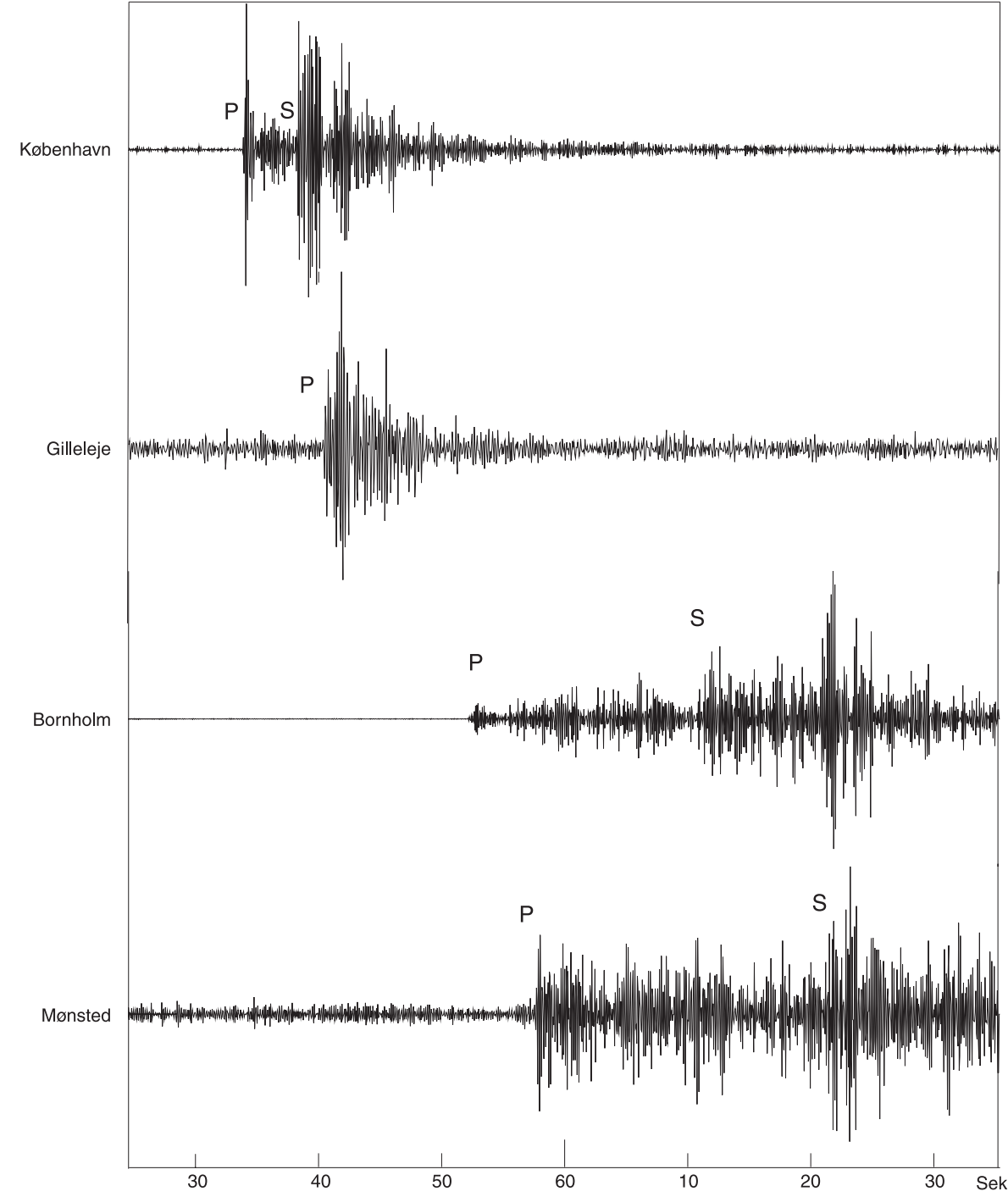

Udslaget for den vertikale komponent for 4 stationer i Danmark iforbindelse med jordskalvet ved Køge d. 23. februar 2004. P er den primare bølge, S er den sekundcere bølge. Stationen på Stevns var ude af drift. (Grafik: Martin Glendrup og Peter Voss)

yderligere oplysninger, kan vi stadigvæk forvente flere detaljer fra de kommende 10 år.

Se om der har været jordskælv!

Kataloget over de danske jordskælv fra 1929 og til 2002 er blevet opdateret på GEUS' hjemmeside ved brug af et ældre lokalise- ringsprogram. Lokaliseringsprocessen er for nylig blevet omlagt. I forbindelse med omlægningen er alle tidligere beregnede jordskælv blevet genberegnet med det nye lokaliseringsprogram SEISAN, der viser god overensstemmelse med det ældre programs lokaliseringer. 
Røde prikker er jordskcelv $i$ perioden 1983 til 1992. Gule prikker er jordskcelv fra 1993 til 2002. STZ = Sorgenfrei-

Tornquist-zonen, $R F H=$ Ringkøbing-Fyn-Højderyggen, $C G$ = Central Graven. (Grafik: Martin Glendrup og Peter Voss

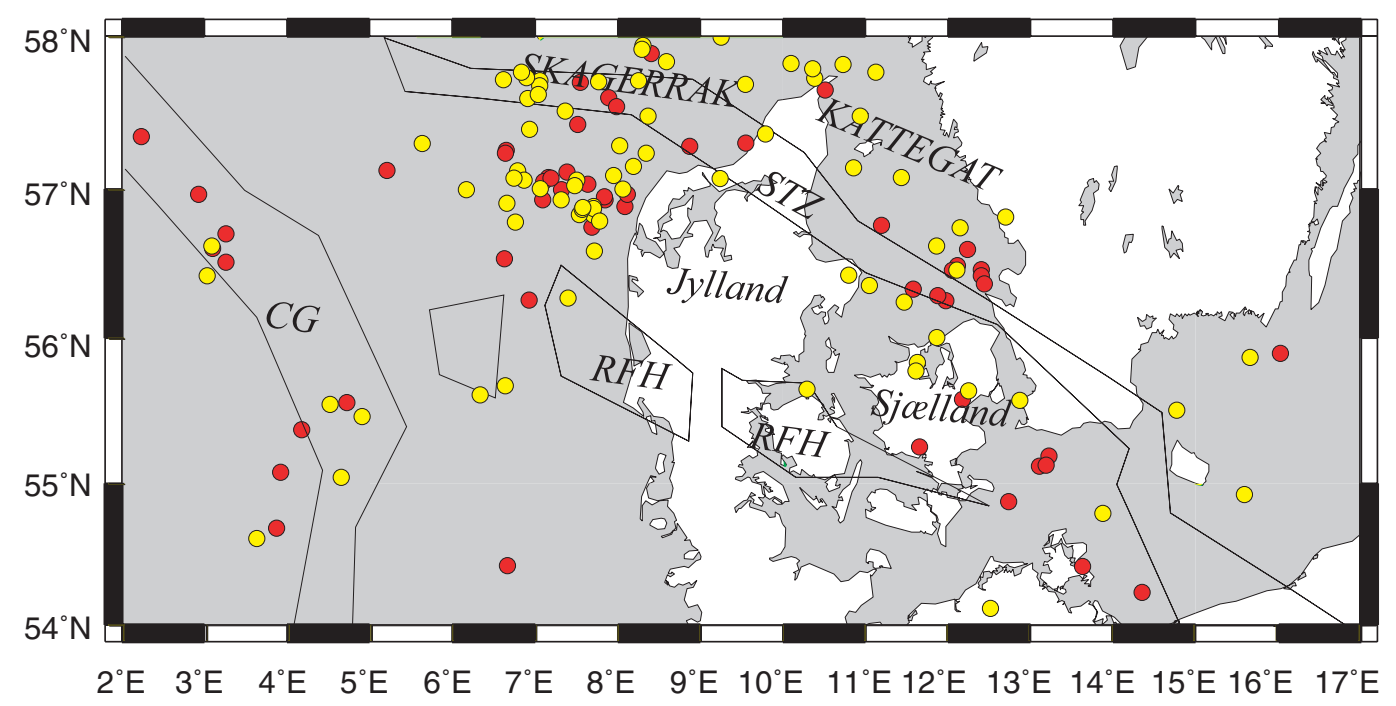

Den nyeste jordskælvsliste, der dækker det danske område, er blevet opdateret til at inkludere alle målte små jordskælv, som vi har kunnet lokalisere. Den kan ses på vores hjemmeside www.geus.dk. Yderligere oplysninger om jordskælv i det Skandinaviske område kan findes hos universitetet i Bergen www.ifjf.uib.no eller hos Universitetet i HelsinkiiFinland, www.seismo.helsinki.fi.

\section{Litteratur:}

Gregersen, S. 2002: Earthquakes and change of stress since the ice age in Scandinavia. Bulletin of the Geological Society of Denmark 49, pages 73-78.

Gregersen, S., Leth, J., Lind, G. \& LykkeAndersen, H. 1996: Earthquake activity and its relationship with geologically recent motion in Denmark. Tectonophysics $257,265-273$

Lykke-Andersen, H. \& Borre, K. 2000: Active tectonics in Denmark - there is life in the Sorgenfrei-Tornquist Zone (in Danish). Geologisk Nyt 6 / 00. 12-13.

Gregersen, S. \& Schmidt, K. 2001:

Tectonics in Denmark - the SorgenfreiTornquist Zone (in Danish). Geologisk Nyt 1/01, 16-17.

Gregersen, S., Hjelme, J. \& Hjortenberg, E. 1998: Earthquakes in Denmark. Bulletin of the Geological Society of Denmark $44,115-127 . I I$ 